\title{
Nanoliposome Encapsulation with Donkey Milk Bioactive Proteins and Its Possible Application in Dermatology and Cosmetics
}

\author{
Hristina Kocić1, Milica Stankovićn, Ivana Arsić \\ ${ }^{1}$ University of Maribor, Medical Faculty, Maribor, Slovenia \\ ${ }^{2}$ University of Niš, Faculty of Medicine, Department of Pharmacy, Niš, Serbia
}

\begin{abstract}
SUMMARY
Nanoliposomes represent natural or synthetic nanoparticles made of phospholipids, which may spontaneously aggregate in an aqueous medium. Their use in dermatology and for cosmetic purposes may offer facilitated delivery in skin via enhanced opening of the tight junctions between the epithelial cell monolayers. As far as their use in dermatology is concerned, both transdermal and local application may offer successful release profile. Donkey milk may have special therapeutic properties when used in cosmetology for skin treatment.

The aim of our study was to establish encapsulation efficacy of nanoliposome loaded with skimmed donkey milk and to explore the efficiency of encapsulation of different skimmed donkey milk concentrations in nanoliposomes.

In our experimental study, it was documented that $1 \%, 2 \%$ and $5 \%$ solutions of skimmed donkey milk were almost equally effectively encapsulated, more than $80 \%$ in $1 \%$ solution of nanoliposomes, while $10 \%$ solution of skimmed donkey milk was encapsulated more efficiently, with $88.9 \%$ in $1 \%$ of nanoliposome solution. Encapsulation can lead to greater efficiency by enabling the use of lower administration doses and preventing the corresponding side effects, which may be the result of higher doses. Skimmed donkey milk is a suitable encapsulation solution.
\end{abstract}

Key words: nanoliposomes, donkey milk, encapsulation efficacy

Corresponding author:

Hristina Kocić

Email: hristinakyu@yahoo.com 


\section{INTRODUCTION}

Nanoliposomes represent natural or synthetic nanoparticles made of phospholipids, which may spontaneously aggregate in an aqueous medium. They can form spherical nanovesicles with spherical shape, known as nanospheres.Phospholipids are responsible for making specific arrangement in a bilayer structure. The polar head groups, which are located on the surface of the membranes, are responsible for contact with an aqueous medium. The fatty acid chains are the hydrophobic chemical groups, which make the core of the nanosphere. They can bind hydrophilic and hydrophobic substances. Polar molecules can be dissolved in the aqueous core, and hydrophobic molecules can be encapsulated in the hydrophobic structure. The size of liposomes can range from $15 \mathrm{~nm}$ and more (1-3).

Donkeys produce milk known throughout history for its nutritional, therapeutic and cosmetic properties. Donkey milk may have special therapeutic properties, being recommended to replace cow's milk in cases where cow's milk protein allergy (CMPA) is manifested and for cosmetic purposes for skin treatment (4-6).

The aim of our study was to establish encapsulation efficacy of nanoliposome loaded with skimmed donkey milk and to explore the efficiency of different nanoliposome concentrations for encapsulation of skimmed donkey milk.

\section{MATERIAL AND METHODS}

Nanoliposomes (NATIPIDE II) were purchased from Lipoid (Germany). Their use in dermatology and for cosmetic purposes may offer facilitated delivery in skin via enhancing the opening of the tight junctions between adjacent cells of the epithelial cell monolayers. In order to make encapsulated donkey milk proteins, skimmed donkey milk was dissolved in water, and $1 \%$, $2 \%, 5 \%$ and $10 \%$ solutions were prepared. They were mixed with $1 \%$ solution of nanospheres in 1:2 ratio. This suspension was allowed to hydrate for $2 \mathrm{~h}$ at room temperature in ultrasound bath and then centrifuged at $6.500 \mathrm{rpm}$ at $4^{\circ} \mathrm{C}$ (using Automatic Refrigerated Centrifuge) according to the method of Gortzi et al. (7).The encapsulation efficiency was estimated after measu-ring protein content by Lowry method, according to the corresponding protein standard. The obtained super-natant where no encapsulated nanoliposome molecules were present was subtracted from the total protein/L content.

Encapsulation efficiency $(\%)=$ (Total proteins-Supernatant proteins) / Total proteins x 100.

\section{RESULTS}

In our experimental study it was documented that $1 \%, 2 \%, 5 \%$ solutions of donkey milk were almost equally effective encapsulated in $1 \%$ nanoliposome solution of about $83.5 \%$, while $10 \%$ solution of donkey milk was encapsulated more efficiently, with $88.9 \%$ in 1\% nanoliposome solution (Figure 1). The obtained results point to the high capacity of nanoliposomes and donkey milk as a very suitable solution for the preparation of nanoliposome-encapsulated product.

\section{DISCUSSION}

Nanoliposomes in the form of nanospheres have been widely used as a drug delivery system for the transport of water-soluble and lipid-soluble molecules. They are polar particles and their polar head groups located on the surface of the membranes permit the encapsulation of hydrophylic and hydrophobic proteins of milk.The encapsulation of different skin care nutrients in nanoliposomes has shown many benefits for skin care because they show a similarity with the membranous structures of skin cells, they are biodegradable, can increase different nutrients stability, can increase their permeation rate and more efficient delivery through the dermal intercellular spaces. They can also decrease allergic and other unfavorable skin reactions. Regarding cosmetic purposes, their amphiphilic structure can adhere to the skin with high affinity and have sustained release, which can prolong the active compound effects. Their phospholipid structure permits the regeneration of constitutive lipids of the skin. From the financial point of view, their preparation is not expensive (7-10).

Donkey milk-derived products were used in cosmetic industry many centuries ago. There is a considerable number of cosmetic products containing the whole milk or milk-derived ingredients, like whey, that are marketed for skin care. It was documented that milk polar lipids may penetrate the intact skin with high encapsulation efficiency (Figures 1-3). 


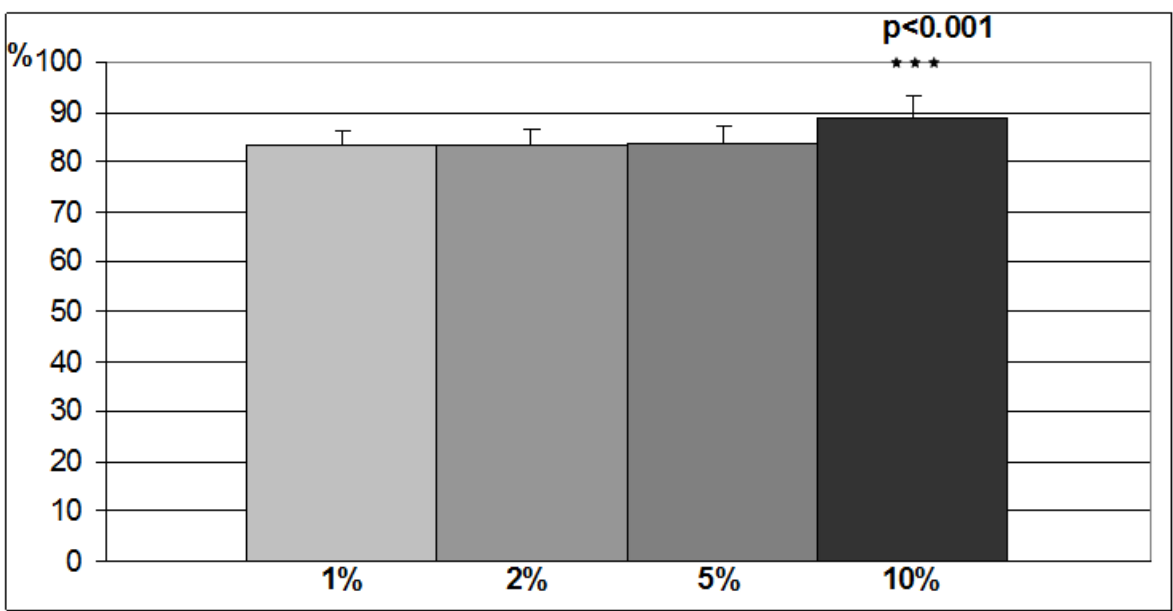

Figure 1.The encapsulation efficacy of $1 \%$ nanoliposomesencapsuled with $1 \%, 2 \%, 5 \%$ and $10 \%$ donkey milk $\mathrm{p}<0.001$ compared to $1 \%, 2 \%$ and $5 \%$

\title{
Calculation of encapsulation efficacy
}

\author{
Encapsulation efficiency $(\%)=($ Total proteins- \\ Supernatant proteins)/ Total proteins $\times 100$
}
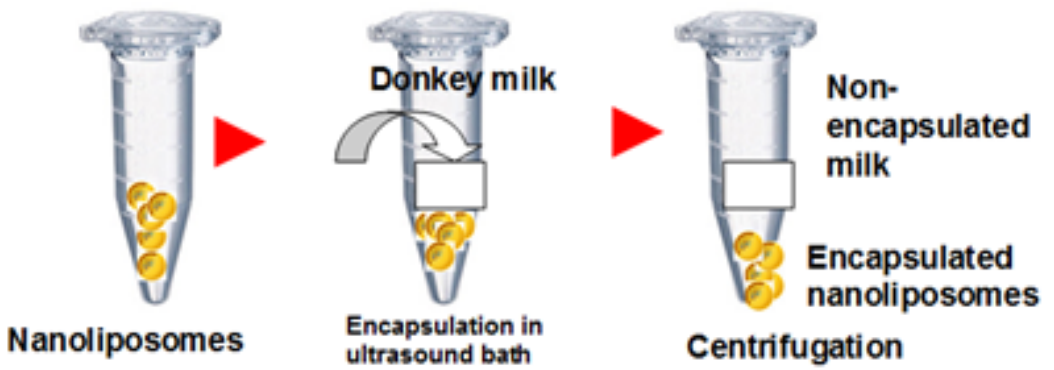

Figure 2.Method and calculation of encapsulation efficiency 


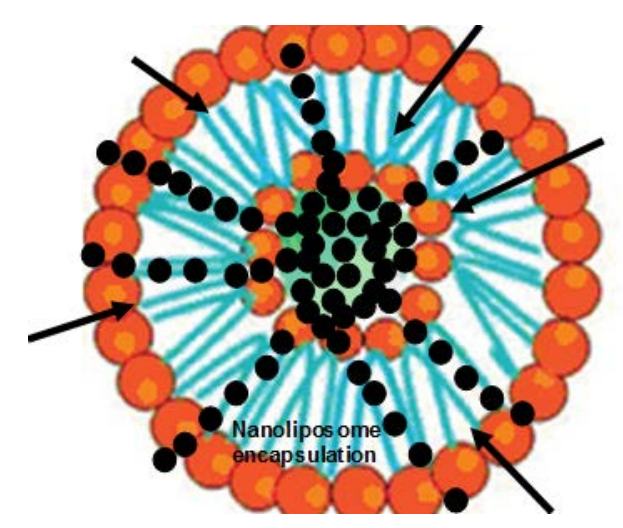

Figure 3. Encapsulation of particles in nanoliposomes

Based on the obtained results on experimental animals, polar lipids of milk may have potential cosmetic use because of dermal penetrating properties and because they are able to regulate the skin cells cycle (4-6).

\section{CONCLUSION}

As it was documented, the encapsulation may constitute an appropriate way to preserve the proper - ties of substances during storage and it may enhance their delivery and consequent physiological effects of skin care formulations. Regarding their use in dermatological applications, both transdermal and local application may offer successful release profile. Encapsulation can lead to greater efficiency also by allowing smaller administration doses, diminishing potential appearance and side effects due to higher doses (7-10). Skimmed donkey milk is a suitable encapsulation solution. 


\section{References}

1. Ekambaram P, Abdul Hasan Sathali A, Priyanka K. Solid lipid nanoparticles: a review. Sci Revs ChemCommun 2012; 2: 80-102.

2. Gonnet M, Lethuaut L, Boury F. New trends in encapsulation of liposoluble vitamins. J Control Release 2010; 146: 276-90

https://doi.org/10.1016/j.jconrel.2010.01.037

3. Cevc G. Transfersomes, liposomes and other lipid suspensions on the skin: permeation enhancement, vesicle penetration, and transdermal drug delivery. Crit Rev Ther Drug Carrier Syst 1996; 13: 257-388. https://doi.org/10.1615/CritRevTherDrugCarrierSyst. $\underline{\text { v13.i3-4.30 }}$

4. Criscione A, Cunsolo V, Bordonaro S et al. Donkeys' milk protein fraction investigated by electrophoretic methods and mass spectrometric analysis. Intern Dairy J 2009; 19: 190-7. https://doi.org/10.1016/j.idairyj.2008.10.015

5. Jirillo F, Magrone T. Anti-inflammatory and antiallergic properties of donkey's and goat's milk. EndocrMetab Immune Disord Drug Targets 2014; 14: $27-37$.

https://doi.org/10.2174/1871530314666140121143747
6. Cunsolo V, Muccilli V, Fasoli Eet al. Poppea's bath liquor: The secret proteome of she-donkey's milk. J Proteomics 2011, 74 : 2083-99 https://doi.org/10.1016/j.jprot.2011.05.036

7. Gortzi O, Lalas S, Chinou I, Tsaknis J. Evaluation of the Antimicrobial and Antioxidant Activities of Origanumdictamnus extracts before and after encapsulation in liposomes. molecules 2007; 12: 932-45. https://doi.org/10.3390/12050932

8. Montenegro L. Nanocarriers for skin delivery of cosmetic antioxidants. J Pharm Pharmacogn Res 2014; 2: 73-92.

9. Bonechi C, Martini S, Ciani Let al. Using liposomes as carriers for polyphenolic compounds: The case of trans-resveratrol. PLoS ONE 2012; 7: e41438. https://doi.org/10.1371/journal.pone.0041438

10. Bonifacio BV, Silva PB, Ramos MA, Negri KM, Bauab TM, Chorilli M. Nanotechnology-based drug delivery systems and herbal medicines: a review. Int J Nanomed 2014; 9: 1-15 


\title{
Enkapsulacija nanolipozoma bioaktivnim proteinima magarećeg mleka i mogućnost primene u dermatologiji i kozmetologiji
}

\author{
Hristina Kocić1, Milica Stankovićn ${ }^{2}$ Ivana Arsić \\ ${ }^{1}$ Univerzitet u Mariboru, Medicinski fakultet, Maribor, Slovenija \\ ${ }^{2}$ Univerzitet u Nišu, Medicinski fakultet, Odsek za farmaciju, Niš, Srbija
}

\section{SAŽETAK}

Nanolipozomi predstavljaju prirodne ili sintetske nanočestice sačinjene od fosfolipida koje mogu spontano da agregiraju u vodenoj sredini. Njihova upotreba u dermatologiji i u kozmetičke svrhe može omogućiti ubrzanu aplikaciju i prodiranje u kožu jer dolazi do lakšeg otvaranja spojeva između epitelnih ćelija. Kada je u pitanju korišćenje u dermatologiji, i transdermalna i lokalna aplikacija su veoma efikasne. Magareće mleko se pokazalo kao potencijalno veoma korisno kada se koristi u kozmetičke svrhe za tretman kože.

Cilj ove studije bio je da se ispita efikasnost enkapsulacije nanolipozoma, koji su tretirani obezmašćenim magarećim mlekom, kao $\mathrm{i}$ da se ispita koliki je kapacitet enkapsulacije u uslovima različitih korišćenih koncentracija mleka.

U našoj eksperimentalnoj studiji pokazano je da je 1\%, 2\% i 5\% rastvora obezmašćenog magarećeg mleka gotovo jednako efikasno enkapsulirano i to više od $80 \%$, kada se koristila koncentracija od $1 \%$ nanolipozoma, dok je $10 \%$ rastvora obezmašćenog magarećeg mleka bilo još efikasnije enkapsulirano i to čak $88,9 \%$, kada se koristila koncentracija nanolipozoma od 1\%. Enkapsulacija supstanci u nanolipozome je proces koji omogućava korišćenje manjih doza potrebnih supstanci, što dovodi do manje šanse da se pojave štetni efekti u poređenju sa većim dozama. Obezmašćeno magareće mleko je rastvor koji je veoma pogodan za metodu enkapsulacije nanolipozoma.

Ključnereči: nanolipozomi, magareće mleko, efikasnost enkapsulacije 